\title{
Study on the Influence of Traffic Management on the Construction of Commercial Facilities
}

\author{
Dody Taufik Absor Sibuea \\ Medan State University, Civil Engineering, Willlem Iskandar Street, Medan Estate, Medan, 20221, Indonesia \\ dodytaufikabsor@unimed.ac.id
}

\begin{abstract}
The development of some activity centre will affecting traffic on its surrounding area. Therefore a study is needed to assess the impact of traffic that occurs as a result of its development. Traffic management used for to determine the potential traffic impacts of a proposed traffic generator. The four main steps of the transportation planning modeling process are trip generation, trip distribution, modal split, and trip assignment. With the assumption that there is a relationship between land use intensity and the number of trips in and out of the location, traffic impact of development on the surrounding area can be forecasted.
\end{abstract}

Keywords: transportation, modeling, traffic.

\section{Introduction}

The expansion of urban areas is currently considered quite rapid in line with the development of community demands for public facilities and social facilities for activities and / or businesses related to offices, shopping centers, education, and so on.

The development of an activity center that attracts or generates traffic at a certain location on the side of the road will affect the surrounding traffic, the traffic impact analysis study is used to predict whether the transportation infrastructure in the area of influence of the development can serve existing traffic, which is raised or drawn by that development [1].

The development plan of showroom on Medan Timur District is estimated to attract traffic which might affect the road performance around the location. Therefore, to calculate the impact of the development plan, it is necessary to conduct a traffic impact study, so that it can be minimized by providing the right solution.

\section{Issue Identification}

The problem caused by the showroom development plan is the increased traffic flow that is expected to result in a decrease in the level of service at intersections, roads, parking, public transportation facilities, and pedestrian facilities around the location. The problem formulations that can be taken in this traffic impact analysis study are as follows: traffic impact in the surrounding area; the implementation plan for road performance decreased and level of Service (LoS) around the road network, and road performance that is affected by development in the future.

\section{Research Objective}

The objective of this study is to predict the impact resulting from a development plan, to determine the form of improvement that needed to accommodate changes that occur as a result of a development plan, and as a monitoring and evaluation for the implementation of traffic management.

\section{Research Method}

Traffic impact analysis is a study that determines whether the traffic on existing roads accommodate that will result from a proposed development [2], which means to determines the potential traffic impacts of a proposed traffic generator. The traffic impact of the planned development of a new area is generally oriented towards a review of the aspects of land use development, associated with efforts to predict the amount of traffic generated and the land to be withdrawn to be planned, as well as efforts to estimate the impact on the surrounding road network. In analyzing traffic management impact requires some of the following information: existing condition, trip generation and traffic volume, trip distribution and assignment, existing and future trip volume, and road capacity analysis [3]

\subsection{Model Development}

Transportation model will provide an overview of the traffic in the studied area. Trip assignment around the study area is added to the base year traffic to determine a real trip assignment on the impact area with the development plan. The four steps of transportation modeling are trip generation, trip distribution, modal split, and trip assignment [4].

\subsubsection{Trip Generation}

The initial stage of the four steps of the modeling process is trip generation, which is accordance with the category of land use in the business area, the concept of trip attraction is used. By the assumption that there is a relationship between land use intensity and the number of trips in and out of the location, a mathematical relationship can be determined that describes the level of attraction of trips to that location.

\subsubsection{Trip Distibution}

Trip Distribution is basically the stage to get the origindestination matrix (O-D Matrix) which will be used in the next process. The distribution basic is the determination of the minimum travel distance path proportional to the intensity of land use in the impact area of activity. 


\subsubsection{Modal Split}

In this stage, there are two type of approach, which is Trip End Model and Trip Interchange Modal Split Model. In this study, Trip-end concept approach will be used to split the total person-trip into vehicle-trip.

\subsubsection{Traffic Assignment}

The last stage is Trip Assignment. This stage uses the MKJI method, where this stage will produce traffic performance indicators which include the degree of saturation, speed, and volume on each road [5].

\subsection{Traffic Behavior}

\subsubsection{Traffic Volume}

The traffic volume on a road varies, depending on the twoway volume, traffic direction, daily volume, monthly volume, annual volume, and on vehicle composition.

\subsubsection{Road Capacity}

According to MKJI (1997), road capacity analysis is expressed by equations [2]:

$$
C=C o \times F C w \times F C s p \times F C s f \times F C c s
$$

Where:

Co = basic capacity

$\mathrm{FC}_{\mathrm{W}}=$ correction factor for road width

$\mathrm{FC}_{\mathrm{SP}}=$ correction factor for road split/direction

$\mathrm{FC}_{\mathrm{SF}}=$ correction factor for side friction

$\mathrm{FC}_{\mathrm{CS}}=$ correction factor for city size

\subsubsection{Volume Capacity Ratio}

$\mathrm{VC}$ ratio is one of the aspect that used to determine road performance parameter, which comparing the existing traffic condition with its capacity. Volume capacity ratio can be obtained by dividing traffic volume with road capacity.

\section{Data Collection and Analysis}

The data collected in this study consists of two kinds of data, which is secondary data and primary data. Secondary data is data obtained from related agencies, while primary data is data obtained through direct field surveys.

\subsection{Existing Conditions}

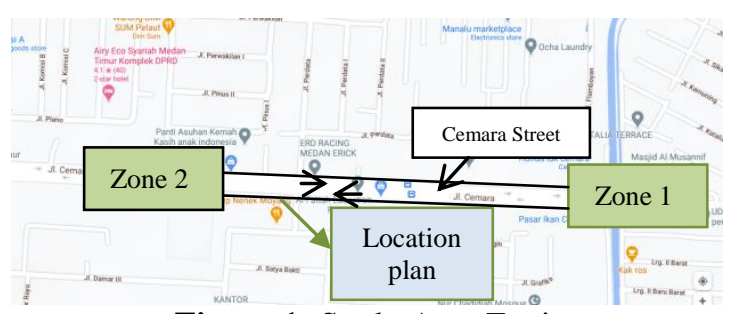

Figure 1: Study Area Zoning

Zoning: This study area is divided into two zones to facilitate the classification of vehicle movements based on the origin and destination of the trip.

\begin{tabular}{|c|l|c|}
\hline Zone & \multicolumn{1}{|c|}{ Coverage Area } & Type of Area \\
\hline 1 & To Cemara Asri Intersection & Commercial \\
\hline 2 & To Krakatau Ujung Street & Commercial \\
\hline
\end{tabular}

\subsubsection{Free Flow Speed dan Model Speed}

Free flow speed calculation for Cemara Street:

$$
\begin{aligned}
P V & =(F V o+F V w) \times F F V s f \times F F V c s \\
& =(57+(-2) \times 0,95 \times 1 \\
& =44,93 \mathrm{~km} / \mathrm{h}
\end{aligned}
$$

Once the free flow speed is obtained, the real speed can be determined. The actual speed calculation is a model that can be used to determine the speed for the planning year.

Table 2: Free Flow Speed Calculation

\begin{tabular}{|c|c|c|c|c|c|c|c|}
\hline Street & Type & Width $(\mathrm{m})$ & $\mathrm{FV}_{0}$ & $\mathrm{FV}_{\mathrm{W}}$ & $\mathrm{FFV}_{\mathrm{SF}}$ & $\mathrm{FFV}_{\mathrm{CS}}$ & $\mathrm{FV}$ \\
\hline Cemara & $6 / 2 \mathrm{D}$ & 11,05 & 57 & -2 & 0,95 & 0,86 & 44,935 \\
\hline Cemara 1 & $6 / 2 \mathrm{D}$ & 11,11 & 57 & -2 & 0,95 & 0,86 & 44,935 \\
\hline
\end{tabular}

Table 3: Model Flow Sped Calculation

\begin{tabular}{|c|c|c|c|c|c|c|}
\hline Street & Type & FV & $\begin{array}{c}\text { VC } \\
\text { Ratio }\end{array}$ & Volume & Capacity & $\begin{array}{c}\text { Model } \\
\text { Speed }\end{array}$ \\
\hline Cemara & $6 / 2 \mathrm{D}$ & 44,94 & 0,21 & 1636,82 & 7764,77 & 42,43 \\
\hline Cemara 1 & $6 / 2 \mathrm{D}$ & 44,94 & 0,18 & 1395,79 & 7764,77 & 42,82 \\
\hline
\end{tabular}

\subsubsection{Trip Distribution}

For existing conditions, the amount of trip distribution is equal as the volume of traffic flow between zones.

Table 4: Traffic Volume Percentage

\begin{tabular}{|c|c|c|c|}
\hline \multirow{2}{*}{ No } & \multirow{2}{*}{ Street } & \multicolumn{2}{|c|}{ Traffic Volume } \\
\cline { 3 - 4 } & & pcu/hour & Percentage \\
\hline 1 & Cemara & 1636,82 & $54 \%$ \\
\hline 2 & Cemara 1 & 1395,79 & $46 \%$ \\
\hline
\end{tabular}

From the results of the volume percentage, the trip generate and attraction then distributed to the road sections. For details regarding the distribution of trips between zones in the study area as follows:

Table 5: Origin Destination Matrix

\begin{tabular}{|c|c|c|c|}
\hline OD & 1 & 2 & Total \\
\hline 1 & 0 & 19656 & 19656 \\
\hline 2 & 17292 & 0 & 17292 \\
\hline Total & 17292 & 19656 & 36948 \\
\hline
\end{tabular}

From the table, shown that the largest number of trips during peak hours is from zone 1 to zone 2 with a total number of trips of 19,656 trip/day.

\subsubsection{Route Choice/Trip Assignment}

Route choice/trip assignment aims to estimate which route will be loaded from the existing trip generation and attraction, in this analysis, route choice will be simulated by using all-or-nothing method approach with capacity restrain or the nearest route.

Table 6: Trip Assignment for Existing Condition

\begin{tabular}{|c|c|c|c|c|c|}
\hline No & Street & $\begin{array}{c}\text { Capacity } \\
(\mathrm{pcu} / \mathrm{h})\end{array}$ & $\begin{array}{c}\text { Volume } \\
(\mathrm{pcu} / \mathrm{h})\end{array}$ & $\begin{array}{c}\text { VC } \\
\text { Ratio }\end{array}$ & LoS \\
\hline 1 & Cemara & 7764,768 & 1636,82 & 0,211 & $\mathrm{~B}$ \\
\hline 2 & Cemara 1 & 7764,768 & 1395,79 & 0,180 & A \\
\hline
\end{tabular}

Table 1: Zoning
It is found that the volume of traffic to the west is higher than that of the east. So that the VC ratio for Cemara 1 is 
0.18 and to the west is 0.21 in front of the plan site.

\subsection{Without Construction Condition}

This stage will explain how traffic performance simulation before construction. Trip distribution before the construction as follows:

Table 7: Trip Distribution Without Construction

\begin{tabular}{|c|c|c|c|}
\hline Zone & 1 & 2 & Total \\
\hline 1 & 0 & 21029 & 21029 \\
\hline 2 & 18500 & 0 & 18500 \\
\hline Total & 18500 & 21029 & 39530 \\
\hline
\end{tabular}

After the trip distribution results are obtained, the next step is to assign the trip so that the road performance and network performance will be obtained.

Table 8: Road Performance for Without Construction Condition

\begin{tabular}{|c|c|c|c|c|c|}
\hline No & Street & $\begin{array}{c}\text { Capacity } \\
(\mathrm{pcu} / \mathrm{h})\end{array}$ & $\begin{array}{c}\text { Volume } \\
(\mathrm{pcu} / \mathrm{h})\end{array}$ & $\begin{array}{c}\text { VC } \\
\text { Ratio }\end{array}$ & LoS \\
\hline 1 & Cemara & 7764,768 & 1751,19268 & 0,23 & $\mathrm{~B}$ \\
\hline 2 & Cemara 1 & 7764,768 & 1493,32072 & 0,19 & $\mathrm{~A}$ \\
\hline
\end{tabular}

The road section in front of the construction site, which is Cemara, with a level of service that is still in good condition, level of service value: $B$.

\subsection{During Construction Condition}

The construction makes an additional load of $34.5 \mathrm{pcu} /$ hour during the construction period because the construction attracted the trips of people working on development for this area.

Table 9: Traffic Performance on Construction Condition

\begin{tabular}{|c|c|c|c|c|c|}
\hline No & Street & $\begin{array}{c}\text { Capacity } \\
(\mathrm{pcu} / \mathrm{h})\end{array}$ & $\begin{array}{c}\text { Volume } \\
(\mathrm{pcu} / \mathrm{h})\end{array}$ & $\begin{array}{c}\text { VC } \\
\text { Ratio }\end{array}$ & LoS \\
\hline 1 & Cemara & 7764,768 & 1671,32 & 0,22 & $\mathrm{~B}$ \\
\hline 2 & Cemara 1 & 7764,768 & 1430,29 & 0,18 & $\mathrm{~A}$ \\
\hline
\end{tabular}

It is shown that there was an increase in the load during the construction period, which is not too significant so that there was only a small addition of trip attraction occur.

\subsection{Trip Generation Forecasting}

\subsubsection{Trip Production Rate}

Trip rates adopted for this study are presented in terms of the number of trips in passenger cars unit (pcu) per hour produced by the activities of the construction plan. It consists of several types of activities that affect the level of trip generation and attraction, which is service facilities. The coefficient that is used as a measure to determine the estimated travel generation and attraction at location study is the number of units.

\subsubsection{Trip Generation and Trip Attraction}

In the operating conditions of all buildings from the site planning, it is estimated that there will be an increase in traffic volume due to additional traffic generation and attraction from the area, as well as an increase in traffic due to vehicle growth.
Table 10: Trip Generation and Trip Attraction Calculation

\begin{tabular}{|c|c|c|c|c|}
\hline \multirow{2}{*}{ Type of Land Use } & \multicolumn{2}{|c|}{ Day Peak } & \multicolumn{2}{c|}{ Mid-day Peak } \\
\cline { 2 - 5 } & In & Out & In & Out \\
\hline Showroom (pcu/unit) & 13,0 & 57,2 & 18,9 & 13,0 \\
\hline
\end{tabular}

In analysis trip generation and trip attraction for the designation of service activities, it is estimated that the maximum generation and attraction will occur in the morning. Analysis of peak hour generation and attraction in the study area will be simulated according to road network conditions during morning and evening peak hour. The number of trips is estimated at $70.2 \mathrm{pcu} /$ hour.

\subsection{Post-construction Condition (Do-nothing)}

This stage will explain how traffic performance simulation after construction. However, at this stage, the codification has changed with the addition of zones for construction plan.

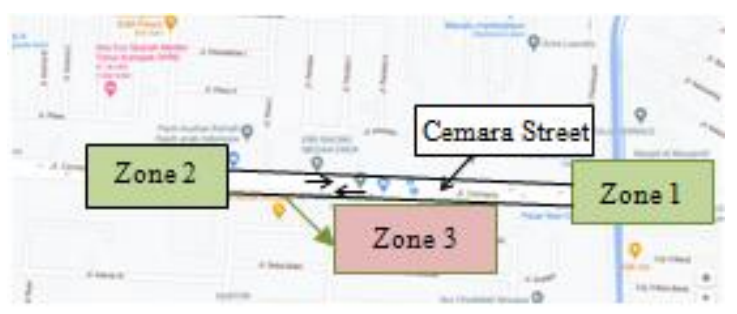

Trip distribution after the construction as follows:

Table 11: Trip Distribution during Operation

\begin{tabular}{|c|c|c|c|c|}
\hline Zone & 1 & 2 & 3 & Total \\
\hline 1 & 0 & 21029 & 619 & 21649 \\
\hline 2 & 18500 & 0 & 483 & 18983 \\
\hline 3 & 461 & 225 & 0 & 686 \\
\hline Total & 18500 & 21029 & 1102 & 41371 \\
\hline
\end{tabular}

After the trip distribution results are obtained, the next step is to assign the trip so that the road performance and network performance will be obtained.

Table 12: Road Performance for After Construction

\begin{tabular}{|c|c|c|c|c|c|}
\hline No & Street & $\begin{array}{c}\text { Capacity } \\
(\mathrm{pcu} / \mathrm{h})\end{array}$ & $\begin{array}{c}\text { Volume } \\
(\mathrm{pcu} / \mathrm{h})\end{array}$ & $\begin{array}{c}\text { VC } \\
\text { Ratio }\end{array}$ & LoS \\
\hline 1 & Cemara & 7764,768 & 2267,19268 & 0,29 & $\mathrm{~B}$ \\
\hline 2 & Cemara 1 & 7764,768 & 1901,32072 & 0,24 & A \\
\hline
\end{tabular}

It is shown that the road in front of the construction site has a level of service that has increased significantly but still in a good service level.

\subsection{Performance Comparison}

Road performance comparison for the categories that have been analyzed at the study area as follows:

Table 13: Performance Comparison

\begin{tabular}{|c|c|c|c|c|c|c|c|c|}
\hline \multirow{3}{*}{ Street } & \multicolumn{2}{|c|}{ Existing } & \multicolumn{2}{|c|}{$\begin{array}{c}\text { With } \\
\text { Construction }\end{array}$} & $\begin{array}{c}\text { Planning Years } \\
\text { Without } \\
\text { Construction }\end{array}$ & \multicolumn{2}{c|}{$\begin{array}{c}\text { Planning } \\
\text { Years } \\
\text { Operating }\end{array}$} \\
\cline { 2 - 9 } & $\begin{array}{c}\text { VC } \\
\text { Ratio }\end{array}$ & LoS & $\begin{array}{c}\text { VC } \\
\text { Ratio }\end{array}$ & LoS & $\begin{array}{c}\text { VC } \\
\text { Ratio }\end{array}$ & LoS & $\begin{array}{c}\text { VC } \\
\text { Ratio }\end{array}$ & LoS \\
\hline Cemara & 0,21 & B & 0,22 & B & 0,23 & B & 0,29 & B \\
\hline Cemara 1 & 0,18 & A & 0,18 & A & 0,19 & A & 0,24 & B \\
\hline
\end{tabular}


From the analysis that has been done, it is known that there has been a decrease in traffic performance for each condition. Before construction and after construction condition, the change in performance still in a stable condition, which is at the level of service "B" which means stable flow and low traffic density.

\section{Conclusion}

Study shows that the impact of business facility development on traffic performance on its surrounding area has made decreasing in traffic performance, but the decreasing in performance still in a stable condition, which is at the level of service "B" that means stable flow and low traffic density. From the analysis the following conclusions can be drawn:

1) The estimated trip generation and attraction of traffic during peak hours, if the construction has been implemented and operates optimally, it is estimated that it will generate new trips of 70,2 pcu/hour.

2) For existing conditions, the performance of Cemara Street to the west has a VC ratio of 0,21 or has a Level Of Service "B". Meanwhile, the other direction has a VC ratio of 0,18 or has a Level Of Service "B".

3) In the conditions before construction, VC Ratio on Cemara to the west is 0,23 with Level of Service B. At the time after construction the $\mathrm{VC}$ ratio increases to 0,29 with level of service $B$.

4) In the conditions before construction, the VC Ratio on Cemara 1 to the east is 0,19 with level of service A. At the time after construction, the $\mathrm{VC}$ ratio increases to 0,24 with level of service B..

\section{References}

[1] Mennon, APG. "Traffic Management in Urban Areas: Case Study of The City of Singapore". Transportation Research Board (TRB). 2003.

[2] F. Greenberg, "Traffic Impact Analysis". American Planning Association. 1984.

[3] Indonesia Highway Capacity Manual (MKJI), 1997.

[4] Morlok, Edward K., "Introduction to Transportation Engineering and Planning". Mc-Graw Hill Inc. 1978.

[5] Khisty, C. John, \& Lall, B. Kent. "Transportation Engineering: An Introduction. Third Edition". Pearson Education Inc. Publishing as Prentice Hall. 2003.

[6] Wells, G. R. "Traffic Engineering: An Introduction". Charles Griffin \& Co. Ltd, London, England. 1979.

[7] Hanumappa, et al. Traffic Characteristic Evaluation and Traffic Management Measures: A Case Study of Dhaward City". The Open Transportation Journal. 2018. 